\title{
The Problem of Comprehensive Analysis of Organic Agriculture as a Factor of Environmental Safety
}

\author{
Yuriy DREVAL ${ }^{1}$, Valentyna LOBOICHENKO ${ }^{2 *}$, Alexandr MALKO $^{3}$, Andrey MOROZOV $^{4}$, \\ Svitlana ZAIKA ${ }^{5}$, Viktor KIS ${ }^{6}$ \\ ${ }^{1-4}$ National University of Civil Defence of Ukraine, Kiev, Ukraine \\ ${ }^{5-6}$ Petro Vasylenko Kharkiv National Technical University of Agriculture, Kharkiv, Ukraine
}

\begin{abstract}
The paper analyses certain aspects of organic agriculture and emphasises the need for an integrated approach in its research. The necessity of using ecologically safe agricultural production as a component of the development of modern civilized states is pointed out in the paper. The method of direct conductometry has been used to study the total mineral composition of plowed soils, which is considered as a component of "green" chemistry methods. The electrical conductivity of aqueous extracts of arable soils, in which mineral and organic fertilizers are applied, is measured. The obtained data vary between 10 and $220 \mu \mathrm{S}$. In the paper, for the first time, the regularities of fluctuations of the data of electrical conductivity of aqueous extracts of arable soils, in which various plant cultures had been grown, were revealed and mineral nitrogen fertilizers or organic fertilizers were introduced. Lower data of electrical conductivity are characteristic of plowed soils, in which mineral fertilizers are applied, which indirectly indicates their depletion. The advantage of using organic fertilizers as a necessary component of organic agriculture has been confirmed. It is noted that a promising area of the research is a complete use of an integrated approach to the organic agriculture being farmed in various European countries.
\end{abstract}

Keywords - Comprehensive analysis, electrical conductivity; environmental safety; organic farming; organic production; soil.

\section{INTRODUCTION}

\subsection{Relevance of the study of organic agriculture as a factor of environmental safety.}

Modern times are characterised by the aggravation of diverse environmental problems, which are increasingly called the common problems of world development. This also applies to the problem of improving agricultural production. Indeed, with the existing approaches to economic management and the rate of consumption, the problem of the complete exhaustion of natural resources is greatly exacerbated. In this respect, the problem of the introduction and development of organic agriculture, hereinafter referred to as OA, is particularly important. In general, such management is a complex system based on a set of methods and resources that provide a viable ecosystem, safe food, healthy food, animal welfare and, ultimately, human security as the highest social value and social justice. According to the latest data, the production of ecologically safe agricultural products is developing in 181 countries of the world, and the market volume of such products reaches 97 billion US dollars [1].

* Corresponding author.

E-mail address: vloboichm@gmail.com 
The issue of such farming over time becomes an increasingly important factor in the domestic and foreign policy of any state, affecting most spheres of human activity [2]. Moreover, more and more often it is about the fact that OA is a component of security as a complicated social and social -and -cultural phenomenon. Therefore, we should talk about the implementation of the Sustainable Development Goals 2016-2030, which are being implemented in many countries according to the strategic approach of the United Nations Organisation, in particular, the issue of creating a sustainable food production system, which contributes to preserving the ecosystem and gradually improving the quality of land.

\subsection{Features of modern research of various aspects of $O A$}

Various aspects of $\mathrm{OA}$ management are mainly investigated by representatives of economics, focusing on purely economic factors and, on this basis, making final conclusions in accordance with the total social effect of this type of business. For example, R. Fuxse named the issue of OA as one of the key issues for the sustainability of the economic system as a whole and the prevention of environmental disaster [3].

However, today another research direction is clearly indicated, which is based on the complexity of the management of OA and on the prospects of such management from the point of view of the sustainable development of public relations. This research direction is represented by G. Bofoy, D. Kreishmane, K. Leitzmann, T. Mannle, R. Opperman, G. Tsaics, B. Jansen and some other researchers. For example, the authors of the collective monograph "Organic Agriculture: Ecological and Economic Imperatives of Development", mention that "organic agriculture can be defined as an integrated system of agro-and-ecosystem management, including an assessment of potential environmental and social risks of organic agricultural production" [4]. Some researchers, for example, G. Gumenyuk and G. Savenko systematise the international principles of OA and draw conclusions that the basic standards of the IFOAM (International Federation of Organic Agricultural Movement - author) have international status and serve as the basis for the development of national standards for organic production or organic processing in different countries of the world [5], [6]. "If GM (genetically modified) plants are grown in Latvia, then all organic agriculture will be endangered, as GM plants tend to force out and destroy weaker plants without modifications," said Dzidra Kreismane, chairman of the board of the Latvian Association of Organic Agriculture [7]. An international trend is the development of various strategies for managing organic agriculture, both in livestock and crop production. They can be unified [8] or characteristic only for a given region [9].

At the same time, there is also a clear over-emphasis on the economic aspects of regulating any sphere of social relations, including those related to the development of advanced forms of agriculture. For example, Gary Becker, who is one of the classics of the Chicago School of Economics and a Nobel laureate in economics, paying tribute to other areas of knowledge, believes, that it is "an economic approach that offers a fruitful and at the same time unified scheme for understanding all human behavior" [10]. Consequently, the need to consider the purely environmental and social aspects of running this type of business, depending on the economic benefits and incomes of entrepreneurs, is growing. However, it is obvious that a full analysis of the problem, indicated in the title of the manuscript, requires a comprehensive analysis and cooperative participation of specialists on the various aspects of social development. 


\subsection{Basic safety assessments as indicators for $\mathrm{OA}$ research}

The concept of "security" is manifold. Among the basic meanings the following ones can be singled out: security as an internal self-awareness of a person, safety as a necessary condition of individual freedom, safety as a condition of the development of society, safety as absence of threats and dangers, technological security, technological ecological security, natural security, national security as a state or international community of states. Public safety is one of the most important conditions of the development of society as a relationship between people in the process of their joint activities. Ecological safety in a general sense means a set of actions and a set of relevant measures and processes that ensure the ecological balance on the planet and in its different regions, preventing losses for an individual, the state and society as a whole.

All measurements and manifestations of safety are largely dependent on economic activity, which covers a large proportion of able-bodied persons and provides the material basis for the existence of society. In this sense the issue of OA, which is distinguished by consistency and complex nature, is acquiring particular importance. In scientific researches, the basis of the integrated approach is the scientific position on the unity of the single and the common, part and whole, and ultimately, the statement on the universal connection of phenomena and their integrity.

Based on the author's exploratory studies, the security of a person is a key aspect in the system of various aspects and manifestations of security [for more information see 11]. This provision is clearly stipulated in the constitutions of many European countries. Thus, in article 3 of the Constitution of Ukraine it is clearly stated that a person, his life and health, honour and dignity, immunity and security are recognised in Ukraine as the highest social value. According to article 1 of the Constitutional Law of the Republic of Latvia "Rights and Obligations of a Person and a Citizen", a human's life, freedom, dignity and rights are the highest value of the State of Latvia.

\subsection{Tasks and methods of research}

The objective of this study, considering the above arguments, is to define a comprehensive analysis of the environmental management as a factor of environmental and public safety by using the applied and general scientific research methods with emphasis on the significance of the conductometric method.

Having been mentioned in this study, the issue of OA as a factor in environmental safety requires the use of integrated and interdisciplinary approaches. It is known that an integrated approach is a research method, which consists in the comprehensive study of a phenomenon based on attracting and coordinating the entire necessary set of diverse sources. Therefore, we should talk about the application of an interdisciplinary approach. Interdisciplinarity is, among other things, not only borrowing the methods and tools of various related sciences, but also integrating these methods into a unified research methodology. Empirical app roaches were also used to analyse the state of organic agriculture in Ukraine, in particular, aqueous extracts of soil samples were experimentally investigated by express and environmentally safe conductometric method, data were processed using standard statistical methods. 


\section{General Problems Of Development of OA}

\subsection{International legal aspects of the development of $O A$}

According to the definition of the International Federation of Organic Agricultural Movement (IFOAM), "Organic agriculture is a production system that supports the health of soils, ecosystems and people. It depends on ecological processes, biodiversity and natural cycles which are characteristic to local conditions, while harmful resources that cause adverse effects are not allowed to be used. OA combines tradition, innovation and science with the goal of improving the state of the environment and promoting the development of equitable relationships and an adequate standard of living."

The definition shows that the problems of the management of OA are marked by a complex nature, including purely economic, as well as legal, environmental, social and other factors. Precision agriculture with the use of experimental methods is part of the solution of this problem [12], [13]. Organic agriculture is also an important motivational point that enables farmers to achieve their professional ambitions [14].

The legal basis for the development of organic farming in European countries is the content of Council Regulation (EC) No 834/2007 of 28 June 2007 on organic production and labeling the organic products, and the Cancellation of Regulation (EEC) No 2092/91. It defines organic production as an integral system of managing and producing food products, which combines the best practices with regard to the preservation of the environment, the level of biological diversity, the preservation of natural resources, the application of high standards of proper maintenance (welfare) of animals and a method of production that corresponds to certain requirements for products manufactured using substances and processes of natural origin. The goal of the Commonwealth legal system, which regulates the organic production sector, to ensure fair competition and the proper functioning of the domestic market for organic products, as well as maintaining and justifying the consumer confidence in products labelled as organic [15].

According to clause (23) of Commission Regulation (EC) No. 889/2008 of 5 September 2008 "Detailed rules for organic production, labelling and controlling the implementation of Council Regulation (EC) No. 834/2007 regarding to organic production and labelling the organic products" transition to an organic system production requires certain periods of adaptation of all the tools and methods used, and depending on the precursor of the product, certain periods should be defined for different sectors of production [16].

\subsection{Features of the development of $\mathrm{OA}$ in Latvia and Ukraine}

In Latvia organic agriculture began to develop after the restoration of independence. Currently, more and more farms produce environmentally friendly products, refusing to use chemical fertilizers and genetically modified organisms. Obviously, natural farming, which does not use agrochemicals, forms the basis of a truly healthy diet.

The following statistical data testify to some intermediate results of the development of this type of management in this country. Latvia is the third country in Europe in terms of the share of land allocated for the production of organic products. The share of organic farms in Latvia is $9.2 \%$ of the total number of agricultural enterprises. The organic production of Latvia is based mainly on small enterprises, but for the past few years the number of such producers has increased by $50 \%$. The number of producers in Latvia now amounts to 129 . The average Latvian resident spends slightly more than 3 euros per year on organic food [17]. 
In accordance with the plans voiced by the representative of the Ministry of Agriculture of Latvia, Maris Valdovskis, $15 \%$ of all agricultural land should be used in organic agriculture by 2020 . It is also necessary to encourage the formation of cooperatives as a way to increase the competitiveness of the industry and by 2020 to achieve such indicators that the share of biological products in public procurement of health and education institutions will be $50 \%$ [18].

Ukraine, having significant potential for the production of organic agricultural products, the export and the consumption in the domestic market, has also achieved certain results in the development of its own organic production.

According to FiBL and IFOAM (The World of Agriculture. Statistics and Trends 2018), in 2016 in Ukraine there were 294 farms that received the status of "organic", and the total area of agricultural land processed in compliance with the principles of organic production was 381.2 thousand hectares ( $0.9 \%$ of the total area of agricultural land in Ukraine), of which 91.6 thousand hectares were in a transitional period. Also in Ukraine, 550 thousand hectares of wild plants are certified. Almost half of Ukraine's organic certified farmland is used for growing crops $(45.4 \%)$. More than $18 \%$ of such land is occupied by oilseeds and another $5.3 \%$ by legumes, as well as vegetables $-1.6 \%$ and fruits $-0.7 \%$ [19]. At the same time, Ukraine ranks the first in the Eastern European region as per the certified area of organic arable land, specialising mainly in the production of cereals, leguminous plants and oilseeds.

New opportunities for expanding the organic agricultural production and developing the organic market are opened by the Association Agreement between Ukraine and the European Union. Section 17 "Agriculture and Rural Development" states that “... cooperation should contribute to the promotion of modern and sustainable agricultural production, but taking into account the protection of the environment and animals ..." [20].

The current legal basis for developing OA in Ukraine should be the Act "About Basic Principles and Requirements for Organic Production, Handling and Labelling Organic Products," which was adopted by the Verkhovna Rada of Ukraine in July 2018. This document defines the areas of organic production, organic food production requirements, certification of organic production and/or circulation of organic products, storage requirements for organic products, etc. In the Clause 18 of Article 1 of this act, organic production is defined as the activity of operators of the market of organic products connected with the production and sale of organic products in accordance with the legislation in the field of organic production, circulating and labelling of organic products [21].

However, the development of OA in Ukraine as a whole remains a matter for individual enthusiasts and cannot be considered satisfactory. Thus, according to international expert organisations, in 2013 the agricultural land sector of Ukraine under organic farming, which was certified by IFOAM, occupied 303.6 thousand hectares which amounted to $0.83 \%$ of the total land area of the country's agricultural land, while in Italy there was $9.05 \%$, and in Germany there was $5.11 \%$.

\section{APPLIED ASPECTS OF OA DEVELOPMENT}

\subsection{Materials and methods of research}

Clarifying the different aspects of the outlined problems is primarily carried out on the basis of an integrated approach, which requires a detailed analysis of the development of agriculture based on the preservation of the ecosystem and the safety of society as a whole. Empirical approaches were also used to analyse the state of organic agriculture in Ukraine, 
in particular, aqueous extracts of soil samples were experimentally investigated by express and environmentally safe conductometric method, data were processed by using standard statistical methods.

Soil samples were taken in September and October 2017 after the crops had been gathered on the fields.

Point samples of agricultural soils were selected by the "diagonal" method at a depth of $15-25 \mathrm{~cm}$. Single samples of reference points were also taken at a depth of $15-25 \mathrm{~cm}$. Soil samples were dried, crushed and passed through a sieve with round holes with a diameter of $1-2 \mathrm{~mm}[22]$.

A portion of the soil prepared in this way, $\mathrm{m}=40 \mathrm{~g}$, was transferred to a glass with a capacity of $300-350 \mathrm{~cm}^{3}, 200 \mathrm{~cm}^{3}$ of distilled water was then poured in, respectively, a ratio of soil to water 1:5, and the suspension was stirred for 5 minutes. After 5 minutes of settling the suspension was filtered through a "white ribbon" filter. The electrical conductivity of the obtained aqueous extract of the sample was measured.

For the analysis, a conductometer EZODO-7021 is used with a measurement range of specific electrical conductivity of $0.01-2000 \mu \mathrm{S}$ and a measurement error of $\max 2 \%$. It is permissible to use other devices with such technical characteristics, with automatic or external control of the temperature of aqueous solutions [23].

Measurement of electrical conductivity is carried out by immersing the sensor of the conductometer in the test solution [24].

For each sample, a series of parallel values of electrical conductivity was obtained, the results were processed using standard statistical methods for the probability $P=0.95$ [25]. Characteristic of the error is the relative standard deviation of $S_{r}$ [25]:

$$
S_{r}=\frac{\sqrt{\sum_{i=1}^{n} \frac{\left(\aleph_{i}-\bar{\aleph}\right)^{2}}{n-1}}}{\bar{\aleph}} \cdot 100 \%,
$$

where $\mathrm{N}$ - is the measured value of conductivity, $\mu \mathrm{S}$;

$\aleph-$ is the average value of electrical conductivity for the test sample, $\mu \mathrm{S}$;

$n-$ is the number of single measurements for one sample, $n=3$.

\subsection{Analysis of the results}

An integrated approach to understanding environmental subtext in the development of organic agriculture requires an applied analysis aimed at the state of affairs in the local and specific farms.

The starting point for the analysis is that today's draft technical regulations [26] are under review in Ukraine and their content generally complies with the requirements of the European Parliament Directive and Council Regulation (EC) No. 834/2007 of 28 June 2007 regarding to organic production and labelling of organic products [15].

The current document on the production of organic products in Ukraine today is the "Detailed rules for the production of organic products (raw materials) of plant origin" [27]. The compliance of the activities of the investigated agricultural enterprise for the production of organic plant products with the requirements of these Detailed Rules are considered in the paper [27].

The activities of the agricultural enterprise, which is taken as a basis for conducting the research, in most of the items comply with the requirements of European and Ukrainian 
legislation on the production of organic plant products, both current ones and those ones which will be introduced in the future.

As of today, the peculiarities of agricultural activities made by Ukrainian enterprises, in particular, the "Detailed rules for the production of organic products (raw materials) of plant origin" cannot be essential for an agricultural company. Some regulations on the activities in the production of organic products are missed. In particular, there is no register of producers of organic products on the website of consumer services of State Service of Ukraine for Food Safety and Consumer Protection the work of which is regulated by the Decree of the Cabinet of Ministers of Ukraine No. 505 of August 8, 2016 [28].

The partial use of nitrogen fertilizers by an agricultural enterprise does not meet the requirements as per the production of organic agricultural products. The company being studied is in a transitional stage of introducing the production of organic plant products.

In this sense, it is important to include experimental studies based on the conductometric method. The electrical conductivity parameter, which is determined in this case, is express, informative and makes it possible to estimate the amount of soluble mineral salts in the test solution, in particular, in the water body [29] or in the water extract of the soil [30]. Electrical conductivity is a characteristic of total salt content and is connected with the salinity of an aqueous solution through coefficients $0.55-0.75$ [31]. Its measurement in a special way also allows identifying the studied samples of aqueous solutions (extracts) and the natural water [32], [33].

The points studied are shown in Fig. 1. They grew previously in the fields plant crops like barley, wheat, buckwheat, sunflower, soybeans and corn (Fig. 1, points 1-7). Mineral nitrogen fertilizers (Fig. 1, points 1-6) and organic fertilizers (Fig. 1, point 7) were put into the soil of the fields before sowing.

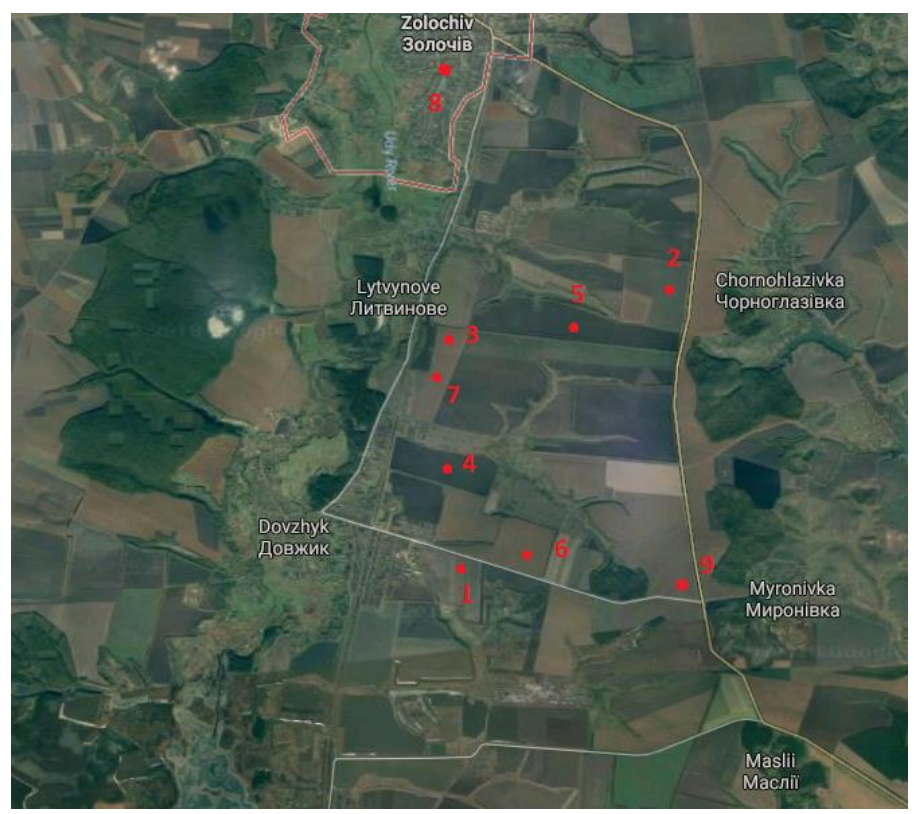

Fig. 1. Places of soil sampled in agricultural fields and fixed points: 1 - the field "barley," 2 - the field "wheat," 3 - the field "corn," 4 - the field "buckwheat," 5 - the field "sunflower," 6 - the field "soybean," 7 - the field "organic corn," 8 - "vegetable garden," 9 - "planting." 
Soil reference points were selected from private farming (Fig. 1, point 8 "vegetable garden") and non-plowed soil (Fig. 1, point 9 "planting"), in which fertilizers were not applied.

Both type fertilizers - mineral nitrogen fertilizers (Fig. 1, point 3) and organic fertilizers (humus) (Fig. 1, point 7) were applied to the soil of the corn field.

The results of determining the electrical conductivity of the studied samples of agricultural soils are presented in Fig. 2. In each field, three soil samples were studied (Fig. 2, samples $1-3)$.

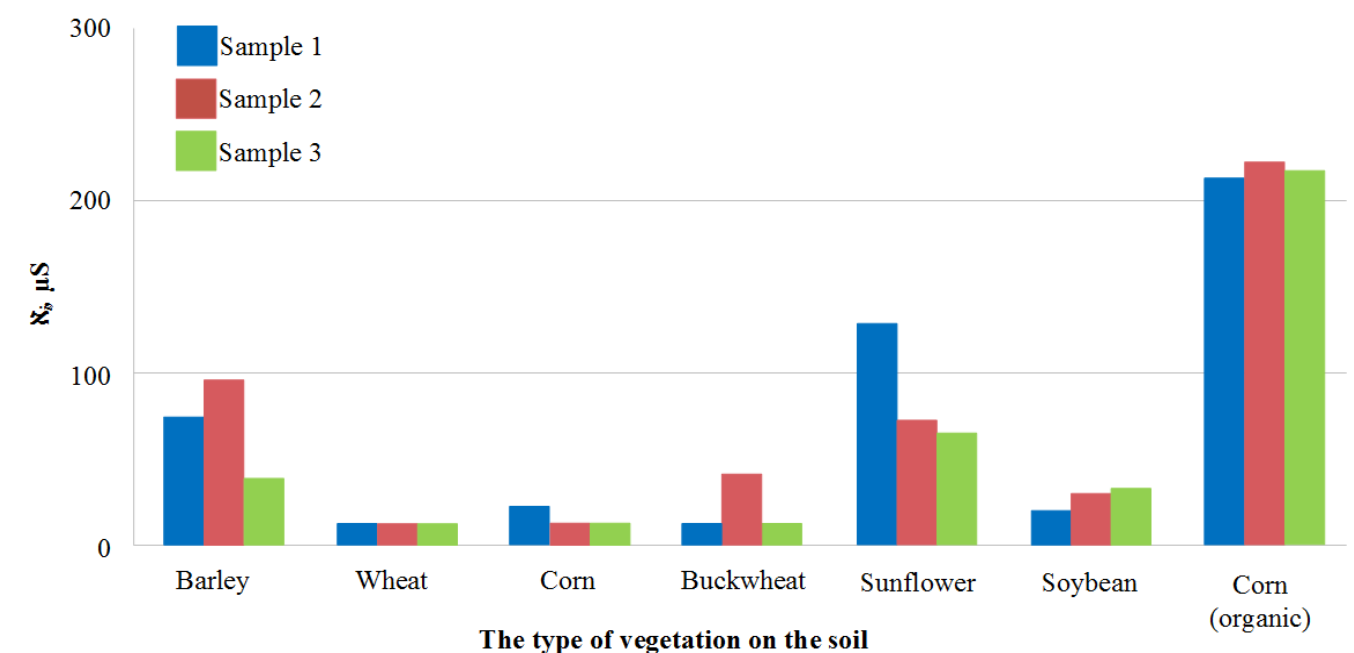

Fig. 2. Data on electrical conductivity of the studied samples of agricultural soils in the fields where different crops grew.

It was found that the average $S_{r}$ value for all measurements does not exceed $5 \%$. As can be seen from the obtained results (Fig. 2), there is a significant variation in the values of electrical conductivities in agricultural fields sown with different crops.

Low data of electrical conductivity are observed in aqueous extracts of soils in the fields sown with wheat, corn, buckwheat, soybeans, the highest data are in the field sown with corn, in which soil organic fertilizers were applied.

The greatest inhomogeneity of the dates of electrical conductivity of aqueous extracts in the soil within one field is observed for barley, sunflower, soybean fields.

The decrease in electrical conductivity from sample 1 to sample 3 (Fig. 2) for barley, sunflower, and corn may be due to the fact that sample 3 was taken closer to the center of the field and nutrients were distributed between a large number of cultivated plants compared to the edge of the field (Fig. 2, sample 1).

The heterogeneity of the data of electrical conductivity in samples 1-3 (Fig. 2) in the fields, where corn, buckwheat, and soybeans grew, is probably due to the uneven application of dry nitrogen mineral fertilizers within the same field.

The uneven application of these fertilizers in different agricultural fields is most likely due to uncharacteristic fluctuations of electrical conductivity in the fields sown with various crops (Fig. 2). Thus, in the soils of the field sown with wheat and corn, there are almost no nutrients, and in aqueous extracts of the soils in the fields sown with sunflower, which also depletes the soils [34], there are almost three times as many electrical conductivity. 
On the other hand, the application of organic fertilizers, Fig. 2, promotes the growth of electrical conductivity in the investigated aqueous extracts and, accordingly, the increase of soluble minerals in the soil.

At the same time, soluble nutrients are distributed more uniformly in the soil in the corn (organic) fields, since electrical conductivity fluctuations in the soil aqueous extracts in one field are insignificant (Fig. 2).

The averaged values of the electrical conductivities of the aqueous extracts of the studied soils in which different cultures grew and the reference points are shown in Fig. 3.

As it is shown in Fig. 3, the greatest value of electrical conductivity, and, accordingly, after harvesting a high amount of nutrients are in the agricultural soils in which organic fertilizers are applied.

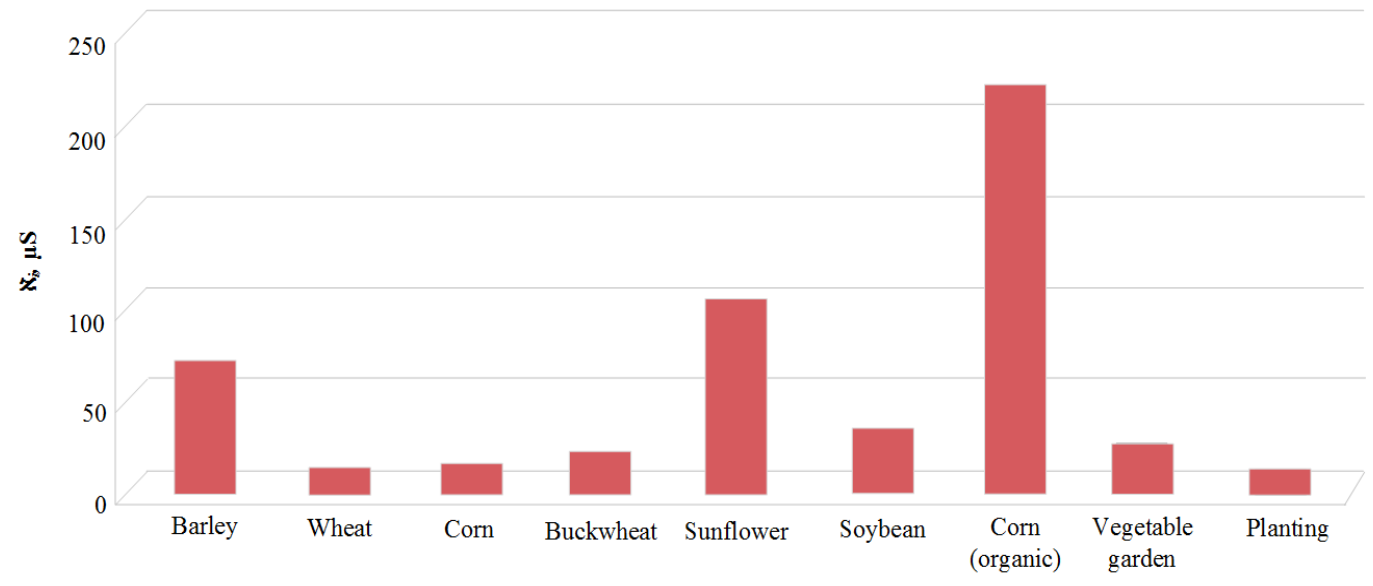

The type of vegetation on the soil

Fig. 3. Data of the electrical conductivity of the studied samples of agricultural soils in the fields where different crops grew (barley, wheat, corn, buckwheat, sunflower, soybean) and reference points (vegetable garden, planting).

Organic fertilizers (manure, humus, etc.) are known to contain nutrients [35] in a safe form for plants and the environment. Accordingly, that is why they are recommended for use by Council Regulation (EC) No. 834/2007 [15] and Commission Regulation (EC) No. 889/2008 [16].

The electrical conductivity of the aqueous extracts of the soils in the studied agricultural fields sowed with wheat and corn is at the level of the electrical conductivity of the aqueous extract of the natural unplowed soil. Accordingly, the soil in these fields is the most depleted. At the same time, a low nutrient content in the unplowed soil can be connected with the metabolic processes in the soil at a deeper level, whereas in the plowed soils this is obviously due to the depletion of plowed soil.

The mineral content in the plowed agricultural soils sowed with buckwheat and soybean is comparable to their content in the soil of the vegetable garden. At the same time, despite plowing, in all cases the soils in the vegetable garden were not exposed to mineral nitrogen fertilizers. That is, it can be assumed that all mineral substances introduced by nitrogen fertilizers were almost completely extracted by these cultures.

The higher value of electrical conductivity in the aqueous extracts in the soil, selected from the vegetable garden of a private house, compared with this value for planting (Fig. 3), is 
most likely to be due to plowing. Plowed soils are known to retain soluble mineral compounds worse [30].

Organic fertilizers contain nutrients, as mentioned above, and are recommended for use in organic agriculture. Only mineral and organic fertilizers were applied to the studied soil of the same type (with corn). Considering that the plant (corn) used part of the nutrients for its vital activity, it can be assumed that the unclaimed dissolved nutrients remained in the soil.

It should be noted that the obvious positive fact is that the application of organic fertilizers increases the nutrient content in the soil by 12 times compared to nitrogen mineral fertilizers, provided that the same crop is grown (corn).

Compared with the reference points, the content of nutrients in the soils with organic fertilizers, respectively, is as 8 times (vegetable garden) and 14 times (planting) higher.

The possibility of using the conductivity parameter data for environmental management and agriculture, in particular, for interpreting the yield map and obtaining input recipes for nutrients is confirmed [36] and for fertilizer management for crop production [37].

To improve the impact of agricultural activities of the enterprise on the state of the soil as a component of the introduction of the production of organic products it is recommended to introduce the process of producing green fertilizers; if it is necessary, to ensure the company additional organic fertilizers from the producers included in the Register of Organic Producers and refrain from the use the nitrogenous mineral fertilizers and completely switch to using organic fertilizers.

It can be noted that the active participation of all parties that should ensure and develop organic agriculture is an important resource for the comprehensive development of rural areas and has a great social effect. The latter, in particular, is expressed in adequate funding and the creation of new jobs, the emergence of additional conditions for the social protection of workers and their families. All these activities should constitute an important component of the proper state of environmental and public safety in general.

\section{Conclusions}

A complex system of management, organic farming is an important factor in environmental and public safety. Modern society has already reached the point beyond whereby traditional, industrial-commercial management, based on short-term economic benefits, threatens the ecological balance and security of humanity and society as a whole. It is organic agriculture that should become one of the components of the unhindered development of mankind.

The analysis of the activities of agricultural enterprises in accordance with the requirements of national and European legislation on the production of organic products and a practical study of the impact of agricultural activities of the enterprise on the soil condition using the electrical conductivity indicator shows that in both cases it is necessary to abandon the use of nitrogen mineral fertilizer and change completely to organic use fertilizers.

For the first time, the regularities of fluctuations in the values of electrical conductivity of aqueous extracts of agricultural soils of enterprises, in which various plant crops were grown and mineral nitrogen fertilizers and organic fertilizers were introduced, were revealed. There is a significant variation in the values of electrical conductivities of aqueous extracts of the soil in agricultural fields sown by various crops both in one and several fields. Low values of electrical conductivity are observed for the aqueous extracts of soils in fields sown with wheat, corn, buckwheat, soybeans, the highest ones are in the field, sown with corn, in which soil organic fertilizers were applied. 
The application of organic fertilizers contributes to an increase in the electrical conductivity of the aqueous extracts of the soil, and, accordingly, 12 times increase in nutrient content in the soil compared with the application of nitrogenous mineral fertilizers, provided that the same crop is grown (corn), 8 times as many of the corresponding values in the plowed soil of the vegetable garden (no fertilizers are applied) and 14 times as many in the unplowed soil planting. In most of the plowed soils, the values of electrical conductivities of aqueous extracts are at the level of reference points, which indirectly indicates their depletion.

A promising direction of research on the identified issues should be a fuller use of an integrated approach to organic farming by enterprises in Ukraine, as well as a comparison of relevant domestic and foreign experience.

\section{REFERENCES}

[1] Willer H., Lernoud J. World of Organic Agriculture: Statistics and Emerging Trends 2019. Bonn: FiBL, Frick and IFOAM, 2019.

[2] Falasca S., Pitta-Alvarez S., Ulberich A. Developing an Agro-Ecological Zoning Model for Tumbleweed (Salsola kali), as Energy Crop in Drylands of Argentina. Environmental and Climate Technologies 2016:18(1):1732. https://doi.org/10.1515/rtuect-2016-0010

[3] Fyuks R. Zelenaya revolyutsiya. Ekonomicheskiy rost bez ushcherba dlya ekologii. (Green revolution: Economic growth without damage to the environment.) Alpina non-fikshn, 2016. (in Russian)

[4] Shkuratov O. I., Chudovskaya V. A., Vdovichenko A. V. Ekologo-ekonomicheskiye imperativy razvitiya organicheskogo sel'skogo khozyaystva v Ukraine. (Organic agriculture: ecological and economic imperatives of development). Kiev: DIA Ltd., 2015. (in Ukrainian)

[5] Gumenyuk G. Standarty mezhdunarodnoy federatsii dvizheniya za organicheskoye sel'skoye khozyaystvo. Osnovnyye printsipy i kharakteristiki. (Standards of the International Federation of the Movement for Organic Agriculture: Basic Principles and Characteristics.) Standardization. Certification. Quality 2012:1:19-22. (in Ukrainian)

[6] Savenko G. E. Organicheskoye sel'skoye khozyaystvo kak prioritetnoye napravleniye dlya realizatsii yedinoy sel'skokhozyaystvennoy politiki Yevropeyskogo Soyuza. (Organic agriculture as a priority area for implementing the common agricultural policy of the European Union). Scientific herald of Uzhgorod National University. Series: International Economic Relations and World Economy 2017:15(2):113-116. (in Ukrainian)

[7] Latviya: organicheskoye zemledeliye pod ugrozoy. (Latvia: organic farming under threat). [Online]. [Accessed 15.12.2018]. Available: https://www.fruit-inform.com/ru/news/70066\#.W-cFdbgqobY. (in Russian)

[8] Le Campion A., Oury F. X., Heumez E., Rolland B. Conventional versus organic farming systems: dissecting comparisons to improve cereal organic breeding strategies. Organic Agriculture 2019:1-12. https://doi.org/10.1007/s13165-019-00249-3

[9] Wallenbeck A., et al. Characteristics of organic dairy major farm types in seven European countries. Organic Agriculture 2018:1-17. https://doi.org/10.1007/s13165-018-0227-9

[10] Becker G. Chelovecheskoye povedeniye: ekonomicheskiy podkhod. Izbrannyye trudy po ekonomicheskoy teorii. (Human behavior: an economic approach. Selected Works on Economic Theory). Moscow: GU VSHE, 2003. (in Russian)

[11] Dreval Yu. D. Bezpeka osobystosti yak faktor suchasnykh derzhavno-upravlins'kykh vidnosyn. (Personality security as a factor of modern state-management relations.) Scientific notes of the Institute of Legislation of the Verkhovna Rada of Ukraine 2015:1:123-126. (in Ukrainian)

[12] Corwin D., Lesch S. Application of Soil Electrical Conductivity to Precision Agriculture. Agronomy Journal 2003: 95(1):455-471. https://doi.org/10.2134/agronj2003.0455

[13] Werban U., Kuka K., Merbach I. Correlation of electrical resistivity, electrical conductivity and soil parameters at a long-term fertilization experiment. Near Surface Geophysics 2009:7:5-14. https://doi.org/10.3997/1873$\underline{0604.2008038}$

[14] Bouttes M., Darnhofer I. Martin G. Converting to organic farming as a way to enhance adaptive capacity. Organic Agriculture 2019:9(2):235-247. https://doi.org/10.1007/s13165-018-0225-y 
[15] Postanova Rady (YES) No. 834/2007 vid 28 chervnya 2007 roku na s'ohodnishniy den' zroblena spetsial'na produktsiya ta markuvannya vidpovidnykh vyrobnytstv, ta skanuvannya Postanovy (YEES) No. 2092/91 (Council Regulation (EC) No 834/2007 of 28 June 2007 concerning organic production and labeling of organic products and repealing Regulation (EEC) No. 2092/91). [Online]. [Accessed 15.12.2018]. Available: http://organicstandard.com.ua/files/standards/ua/ec/EU\%20Reg_834_2007\%20Organic\%20Production_UA.pdf. (In Ukrainian)

[16] Commission Regulation (EC) No. 889/2008 of 5 September 2008. Detal'ni pravyla shchodo orhanichnoho vyrobnytstva, markuvannyai kontrolyu dlya vprovadzhennya Postanovy Rady (YES) No. 834/2007stosovno orhanichnoho vyrobnytstva i markuvannya orhanichnykh produktiv. (Detailed rules on organic production, labeling and control for the implementation of Council Regulation (EC) No. 834/2007 on organic production and labeling of $\begin{array}{llll}\text { organic products). } \quad \text { [Online]. 1.12.2018]. Accessed } & \text { Available: }\end{array}$ http://organicstandard.com.ua/files/standards/ua/ec/EC_Reg_889_2008_Implementing_Rules_UA.pdf. (In Ukrainian)

[17] Mikhalkevich K. A. Ekooriyentirovannoye sel'skoye khozyaystvo: opyt Latvii. (Eco-oriented agriculture: the experience of Latvia.) Presented at 68th Scientific and Technical Conference of Pupils, Students and Undergraduates, Minsk, Belarus, 2017. (In Russian)

[18] Valdovski M. Meropriyatiya dlya razvitiya organicheskogo sel'skogo khozyaystva Latvii. (Events for the development of organic agriculture in Latvia). Presented at $2^{\text {nd }}$ International Scientific and Practical Conference “Organic Agriculture: Development Experience Abroad and Implementation in Belarus,” Minsk, Belarus, 2013. [Online]. [Accessed 15.12.2018]. Available: https://www.slideshare.net/cesbelarus/ss-28360078. (in Russian)

[19] Federatsiya Organichnogo Rukhu Ukraini. (Organic in Ukraine). The official website of the Federation of Organic Movement of Ukraine. [Online]. [Accessed 15.12.2018]. Available: http://www.organic.com.ua. (In Ukrainian)

[20] Uhoda pro asotsiatsiyu mizh Ukrayinoyu, z odniyeyi storony, ta Yevropeys'kym Soyuzom, Yevropeys'kym spivtovarystvom $\mathrm{z}$ atomnoyi enerhiyi i yikhnimy derzhavamy-chlenamy, $\mathrm{z}$ inshoyi storony. (Association Agreement between Ukraine, on the one hand, and the European Union, the European Atomic Energy Community and their Member States, on the other hand) [ratified by a statement by the Law No. 1678-VII 16.09.2014] . [Online] [Accessed 15.12.2018]. Available: http://zakon0.rada.gov.ua/laws/show/984_011. (In Ukrainian)

[21] Pro osnovni pryntsypy ta vymohy do orhanichnoho vyrobnytstva, obihu ta markuvannya orhanichnoyi produktsiyi. (On the basic principles and requirements for organic production, circulation and labeling of organic products). Law of Ukraine dated July 10, 2018, No. 2496-VIII. [Online]. [Accessed 15.12.2018]. Available: http://zakon3.rada.gov.ua/laws/show/2496-19/print1509606909496659. (In Ukrainian)

[22] DSTU 4287:2004 Quality of soil. Sampling Valid from April 30, 2004 K.: Derzhspozhyvstandart of Ukraine, 2005. (In Ukrainian)

[23] Andronov V., Pospelov B., Rybka E. Increase of accuracy of definition of temperature by sensors of fire alarms in real conditions of fire on objects. Eastern European Journal of Enterprise Technologies 2016:4(5(82)):38-44. https://doi.org/10.15587/1729-4061.2016.75063

[24] DSTU 8346:2015 Quality of soil. Methods of determination of specific conductivity, $\mathrm{pH}$ and dense residue of aqueous extract. Valid from 01.07.2017, K.: Derzhspozhyvstandart of Ukraine. 2015. (In Ukrainian)

[25] Dvorkin V. I. Metrologiya i obespecheniye kachestva kolichestvennogo khimicheskogo analiza. (Metrology and quality assurance of quantitative chemical analysis.) Moscow: Khimiya, 2001. (in Russian)

[26] Technical regulations on organic production and labeling of food products and yeast. Project. [Online]. [Accessed 15.12.2018]. Available: http://www.ecolabel.org.ua/novini/406-new.html. (in Ukrainian)

[27] Pro zatverdzhennya Detal'nykh pravyl vyrobnytstva orhanichnoyi produktsiyi (syrovyny) roslynnoho pokhodzhennya (Detailed rules for the production of organic products (raw materials) of vegetable origin), approved by the Resolution of the Cabinet of Ministers of Ukraine of August 31, 2016, No. 587 [Online]. [Accessed 15.12.2018]. Available: http://zakon5.rada.gov.ua/laws/show/587-2016-\%D0\%BF. (in Ukrainian)

[28] The procedure for maintaining the Register of producers of organic products (raw materials), approved by the Cabinet of Ministers of Ukraine Decree No. 505 of August 8, 2016. [Online]. [Accessed 15.12.2018]. Available: http://www.kmu.gov.ua/control/uk/cardnpd?docid=249240998. (in Ukrainian)

[29] Loboichenko V. M., Vasyukov A. E., Tishakova T. S. Investigations of Mineralization of Water Bodies on the Example of River Waters of Ukraine. Asian Journal of Water, Environment and Pollution 2017:14(4):37-41. https://doi.org/10.3233/ajw-170035

[30] Loboichenko V. M. Patterns of mineralization modification of water extracts of cultivated soils of Lozivsky District of Kharkiv Oblast. Visnyk of Lviv State University of Life Safety 2015:12:67-76. [Online]. Available: http://repositsc.nuczu.edu.ua/handle/123456789/1653.

[31] Hem J. D. Study and Interpretation of the Chemical Characteristics of Natural Water. Second Edition - Geological Survey Water Supply Paper 1473. Washington: United States Government Printing Office, 1970.

[32] Vasyukov A., Loboichenko V., Bushtec S. Identification of bottled natural waters by using direct conductometry. Ecology, Environment and Conservation 2016:22(3):1171-1176. https://doi.org/10.32353/khrife.2016.32 
[33] Loboichenko V., Andronov V., Strelec V. Evaluation of the metrological characteristics of natural and treated waters with stable salt composition identification method. Indian Journal of Environmental Protection 2018:38(9):724-732.

[34] Chumak V. S., Desyatnik L. M., Kohan A. V. Pozhyvnyy rezhym zernovykh i oliynykh kul'tur na chornozemakh Ukrayiny. (Nutritional regime of cereals and oilseeds on Chernozems of Ukraine.) Bulletin of the Institute of Agriculture of the steppe zone 2012:3:131-134. [Online]. [Accessed 15.12.2018]. Available: http://nbuv.gov.ua/UJRN/bisg_2012_3_38. (In Ukrainian)

[35] Ozlu E., Kumar S. Response of Soil Organic Carbon, pH, Electrical Conductivity, and Water Stable Aggregates to Long-Term Annual Manure and Inorganic Fertilizer. Soil Science Society of America Journal. 2018:82(5):12431251. https://doi.org/10.2136/sssaj2018.02.0082

[36] Lech M., Fronczyk J., Radziemska M., Sieczka A., Kazimierz G., Koda E., Lechowicz Z. Monitoring of total solids agricultural lands using electrical conductivity measurements. Applied Ecology and Environmental Research 2016:14(4):285-295. https://doi.org/10.15666/aeer/1404_285295

[37] Visconti F., De Paz J. New Trends and Developments in Metrology. Electrical Conductivity Measurements in Agriculture: The Assessment of Soil Salinity 2016. https://doi.org/10.5772/62741

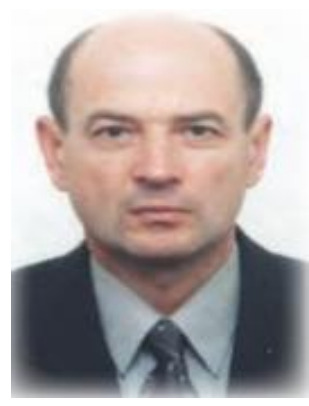

Yuriy Dreval, Doctor of Sciences at the state administration (2011), professor (2014), professor of the Department of occupational, technogenic and environmental safety of the National University of Civil Defence of Ukraine.

The main areas of scientific activity are research in the areas of globalization as a complex phenomenon, the development of people's representation in the difficult conditions of the present and international social and labor standards. Specific scientific achievements include the clarification of the place of nation-state in the conditions of globalisation, the characteristics of people's representation as a complex socio-political and socio-cultural phenomenon and the implementation of the principles of the International Labor Organization in the practice of national governments. He is the author of dozens of publications in specialised scientific journals.

E-mail: drevaly@ukr.net

ORCID iD: https://orcid.org/0000-0002-7347-9433

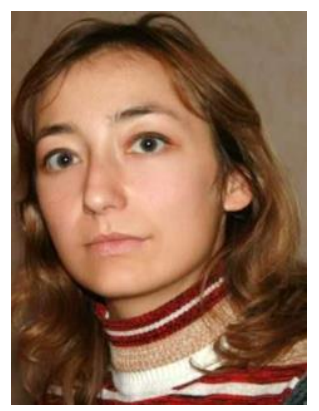

Valentyna Loboichenko, Associate Professor of the Department of occupational, technogenic and environmental safety of the National University of Civil Defence of Ukraine, Ph. Dr. (Chemical Sciences) (2009), Senior Researcher (2014). Since 2011 working at the National University of Civil Defence of Ukraine.

The main research area is the study of the state of water and soils and their pollution. Scientific interests include the improvement of methods for studying environmental objects, the investigation of environmental characteristics fire extinguishing substances, the development of new criteria for the identification of water and aqueous solutions, including water extracts. She has a number of publications in specialized scientific journals devoted to the study of pollution of environmental objects under the anthropogenic load, and not exposed to it. Valentyna takes part in various scientific conferences, dedicated to protecting the environment and humans.

E-mail: vloboichm@gmail.com

ORCID iD: https://orcid.org/0000-0001-5188-6479

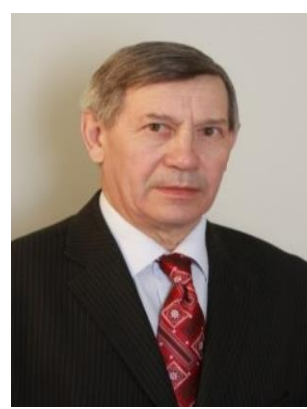

Alexandr Malko, Associate Professor of Department of occupational, technogenic and environmental safety of the National University of Civil Defence of Ukraine. Candidate of Military Sciences (1985), Associate Professor (1990).

Alexandr has more than 70 scientific papers on issues of life safety, technological environmental safety, and labor protection. The main areas of studies are research related to the examination of the state of man-made and environmental safety of industrial facilities. Scientific interests include improving the existing methodology and developing a model for predicting accidents at potentially dangerous facilities, including the study of labor protection issues.

E-mail: malko_ad@ukr.net

ORCID iD: https://orcid.org/0000-0003-4868-7887 


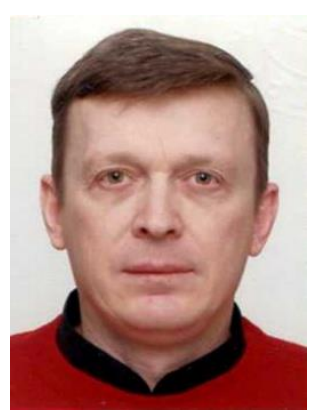

Andrey Morozov, Associate Professor of the Department of occupational, technogenic and environmental safety of the National University of Civil Defence of Ukraine, PhD (Technical Sciences) (2010), Associate Professor (2011). Since 2005 he is working at the National University of Civil Defence of Ukraine.

The field of research includes the safety of humans and environmental objects. Research interests are related to studies of methods of thermal imaging control of biological objects, tools for control equipment for the needs of environmental monitoring of equipment of energy generating facilities, the ecological and fire status of the biotic and abiotic components of natural and anthropogenic ecosystems, development and improvement of methods for monitoring and studying the parameters of their condition. He has a number of publications in Ukrainian and foreign scientific journals, a regular participant in scientific conferences.

E-mail: morozovaniv@ukr.net

ORCID iD: https://orcid.org/0000-0003-2581-0192

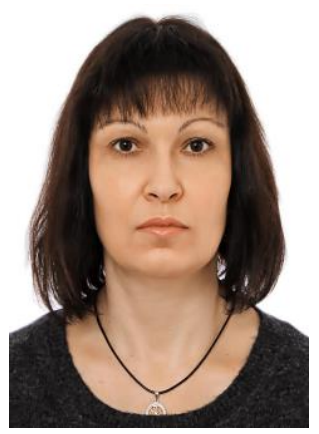

Svitlana Zaika, Candidate of Economic Sciences (2015), Associate Professor (2018), Director of the Academic Institute of Business and Management, the assistant professor of the Department of Production, Business and Management of Kharkiv Petro Vasylenko National Technical University of Agriculture.

The field of scientific interests is the study of the state of the economy in the conditions of European integration processes and transformational changes, the development of concepts, methods and mechanisms of management of economic activities of enterprises, management of innovation and investment activities of enterprises in an unstable environment; analysis and evaluation of investment projects in the field of economy and entrepreneurship; substantiation of the use of alternative energy sources.

She is the author and co-author of over 250 scientific publications, including 12, which are indexed in international science-computer bases.

E-mail: zaika.svitlana1975@gmail.com

ORCID iD: https://orcid.org/0000-0001-8132-7643

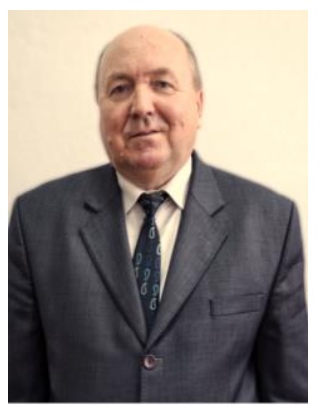

Viktor Kis, Associate Professor of the Department of Mechatronics and Machine Parts in Kharkiv Petro Vasylenko National Technical University of Agriculture since 2006, PhD (2005), Associate Professor (2010).

The main areas of research are related to the study of the state of natural objects. Scientific interests include the improvement of the existing tillage technologies

He has a number of publications in specialised scientific journals and participates in various scientific specialised conferences.

E-mail: vkisprof@ukr.net

ORCID iD: https://orcid.org/0000-0002-7014-4873 